\section{Cerebral Venous Sinus}

\section{Thrombosis: Gender}

\section{Differences in Ten Years}

\section{Experience}

Tuba Aydemir Ozcan', Hasan Meral' ${ }^{2}$ Serkan Ozben ${ }^{3}$, Raziye Tiras ${ }^{4}$, Husniye Hakyemez ${ }^{4}$, Oya Ozturk, Aytul Mutlu4, Belgin Petek Balci, Ozlem Cokar ${ }^{5}$, Feriha Ozer ${ }^{6}$

'Assist. Prof. Dr., ${ }^{6}$ Prof. Dr., Ordu University, Faculty of Medicine, Department of Neurology, Ordu - Turkey ${ }^{2}$ Neurologist, Çanakkale Anatolian Hospital,

Department of Neurology, Canakkale - Turkey ${ }^{3}$ Neurologist, Kafkas University, Faculty of Medicine, Department of Neurology, Kars - Turkey ${ }^{4}$ Neurologist, Haseki Training and Research Hospital, Department of Neurology, Istanbul - Turkey

${ }^{5}$ Assoc. Prof. Dr., Haseki Educational and Research Hospital, Department of Neurology, Istanbul - Turkey

\title{
ABSTRACT
}

Cerebral venous sinus thrombosis: gender differences in ten years experience

Objective: Cerebral venous sinus thrombosis (CVST) is an uncommon subtype of stroke. CVST is much more common in women than men with a ratio of three to one. This women preponderance is attributed to gender-specific risk factors (GSRF). In many patients, symptoms develop over days or weeks. In some patients, clinical presentations are nonspesific.

Patients and Methods: We reviewed the records of patients with CVST treated at Neurology department of Haseki Training and Research Hospital between 2001-2011, which diagnoses were confirmed with cranial magnetic resonance imaging (MRI) and magnetic resonance venography (MRV). Thirty-four patients were included the study. Women/men ratio was 3.25/1. We analyzed the demographic features, comorbid conditions, clinical presentation, neuroradiological findings.

Results: Thirty-four patients were included the study. Headache was present in all patients and it was present as isolated in $47.1 \%(n=16)$ of the patients. In $52.9 \%$ ( $n=18)$ of the patients onset of the symptoms were subacute, $29.4 \%$ ( $n=10)$ chronic, $17.6(n=6)$ acute. Of all patients, $76.5 \%(n=26)$ were women. Transverse sinus was the mostly affected sinus as either isolated or with the other CSVT in both groups (in 20 women and 8 men). The most common presentation symptom (43.78\%) in women was headache whereas; it was intracranial hypertension $(34.78 \%)$ in men. Half of our women patients with GRSF; 7 (26.92\%) women were oral contraceptives user and 5 (15.38\%) women were in pregnancy or puerperium period.

Conclusion: We have found differences between women and men in the presentation and risk factors.

Key words: Gender, risk factors, sinus thrombosis

\section{ÖZET}

Serebral sinus ven trombozu: On yıllık tecrübede cinsiyet farkllıkları

Amaç: Serebral sinus ven trombozu (SSVT) inmenin nadir nedenlerindendir. SSVT kadınlarda erkekleklere göre üçe bir oranında daha sık görülür. Bu kadın baskınlığı cinsiyete özgü rik faktörlerine bağlanmaktadır. Hastaların çoğunda semptomlar günler veya haftalar içinde yerleşmektedir. Bazı hastalarda klinik görünüm nonspesifik olmaktadır.

Yöntem: Haseki Eğitim ve Araștırma Hastanesinde 2001-2011 yılları arasında cranial MR ve MR venografi ile tanısı doğrulanarak SSVT tedavisi almış hasta kayıtlarını inceledik. Çalışmaya otuz dört hasta dahil edildi. Kadın/ erkek oranı 3.25/1 idi. Hastaların demografik özelliklerini, komorbid durumlarını, klinik görünümlerini, nöroradyolajik bulguların inceledik.

Bulgular: Çalışmaya otuz dört hasta dahil edildi. Başağrısı hastaların \%47.linnde $(n=16)$ izole olmak üzere tüm hastalarda mevcuttu. Semptomların başlangıcı hastaların \%52.9'unda ( $n=18)$ subakut, \%29.4'ünde $(n=10)$ kronik, \%17.6'sında $(n=6)$ akut idi. Tüm hastaların \%76.5'i $(n=26)$ kadındı. Her iki cinsiyette de en sık etkilenen sinus transvers sinus olarak saptandı (20 kadın ve 8 erkek). Başvurudaki en sık semptom kadınlarda başağııs (\%43.78) iken, erkeklerde intracranial hipertansiyon (\%34.78) idi. Cinsiyete özgü risk faktörü saptanan kadın hastalarımızdan \%26.92'si ( $n=7)$ doğum control hapı kullanmakta, \%15.38'i $(n=5)$ ise gebelik veya lohusa dönemindeydi.

Sonuç: Klinik görünüm ve risk faktörleri açısından kadın ve erkeklerde farklılılar olduğunu gözlemledik. Anahtar kelimeler: Cinsiyet, risk faktörleri, sinus trombozu

Address reprint requests to / Yazışma adresi: Assist. Prof. Dr. Tuba Aydemir Ozcan, Ordu University, Faculty of Medicine, Department of Neurology, Cumhuriyet Yerleskesi, 52200 Ordu - Turkey

Phone / Telefon: +90-452-226-5214

E-mail address / Elektronik posta adresi: dr_aydemir@yahoo.com

Date of receipt / Geliș tarihi: September 18, 2012 / 18 Eylül 2012

Date of acceptance / Kabul tarihi: October 13, 2012 / 13 Ekim 2012 


\section{INTRODUCTION}

$\widetilde{C}$ erebral venous sinus thrombosis (CVST) is an uncommon subtype of stroke (1). The mean age is 37-38 years, but it can be seen in all ages $(1,2)$. It is associated with infections, neoplasm, pregnancy, puerperium, systemic diseases, dehydration, oral contraceptives (OCPs), and coagulopathies $(3,4)$. In 30\% of the patients, underlying pathology could not be identified (2). In young to middle-aged adults, CVST is much more common in women than men with a ratio of three to one (5). This women preponderance is attributed to gender-specific risk factors (GSRF) such as OCPs, pregnancy and hormon replacement therapy (HRT) (1). In the Middle East countries (Persian Gulf region, Turkey and North Africa) Behcet disease is mostly reported as the causative risk factor (33-36\%) (6).

The superior sagittal sinus (SSS) and the transverse sinuses are mainly affected with a rate of $72 \%$ and $70 \%$, respectively. More than one sinus is affected in nearly one-third of patients (1).

CVST has a wide spectrum of clinical presentation. In $70-90 \%$ of the patients, the presenting symptom is headache. In $25-75 \%$ of the patients, focal neurologic deficits (FND) are present. In many patients, symptoms develop over days or weeks. In some patients, clinical presentations are nonspecific. Therefore, there is not a defined clinical syndrome $(1,7)$.

In this study, we aimed to evaluate the neurological examinations, etiology, and imaging findings of our patients with CVST.

\section{METHODS}

We reviewed the records of patients with CVST treated at the Neurology department of Haseki Training and Research Hospital between 2001-2011, whose diagnoses were confirmed with cranial magnetic resonance imaging $(\mathrm{MRI})$ and magnetic resonance venography (MRV).

Thirty-four patients were included in the study. Women/men ratio was 3.25/1. We analyzed demographic features, comorbid conditions, clinical presentations and neuro-radiological findings. According to the time of onset of symptoms, patients were defined as acute (<48 hours), sub-acute (48 hours-30 days) and chronic (>30 days). The onset symptoms were classified as focal neurological syndrome (FND or seizure), intracranial hypertension (ICH), consciousness deficits, isolated headache, and infection.

Descriptive statistics are reported as mean and range. Categorical data were analyzed with chi-square test. Continuous data were analyzed with Mann-Whitney U test. Probability values $<0.05$ were considered as significant.

\section{RESULTS}

Thirty-four patients were included in the study. Headache was present in all patients and it was the only symptom in $47.1 \%(n=16)$ of the patients. In $52.9 \%$ $(n=18)$ of the patients the onset of the symptoms were

Table 1: Characteristics of the patients

\begin{tabular}{|c|c|c|c|c|}
\hline & Women $(n=26)$ & $\operatorname{Men}(n=8)$ & $\begin{array}{c}\text { Statistical analyses } \\
\chi^{2} / \text { Mann-Whitney } U\end{array}$ & p \\
\hline Age, Mean \pm SD & $35.11 \pm 12.33$ & $27.25 \pm 8.62$ & 0.12 & NS \\
\hline \multicolumn{5}{|l|}{ Onset of symptoms } \\
\hline Acute, n (\%) & $5(19.23 \%)$ & $1(12.5 \%)$ & & \\
\hline Sub-acute, n (\%) & $13(50 \%)$ & $5(62.5 \%)$ & 0.82 & NS \\
\hline Chronic, n (\%) & $8(30.77 \%)$ & $2(25 \%)$ & & \\
\hline Headache, n (\%) & $13(50 \%)$ & $3(37.5 \%)$ & 0.53 & NS \\
\hline Focal neurologic syndrome, n (\%) & $5(19.23 \%)$ & $2(25 \%)$ & 0.71 & NS \\
\hline Intracranial hypertension, n (\%) & $8(30.77 \%)$ & $3(37.5 \%)$ & 0.70 & NS \\
\hline Venous infarction, $\mathrm{n}(\%)$ & $7(26.93 \%)$ & $3(37.5 \%)$ & 0.54 & NS \\
\hline Delta sign, n (\%) & $1(3.85 \%)$ & $1(12.5 \%)$ & 0.36 & NS \\
\hline Seizure during hospitalization, $\mathrm{n}(\%)$ & $3(11.54 \%)$ & $3(37.5 \%)$ & 0.08 & NS \\
\hline
\end{tabular}

$\chi^{2}$ :Chi-square test, NS: Not Significant, SD: Standard Deviation 
sub-acute, in $29.4 \%(\mathrm{n}=10)$ chronic, and in $17.6 \%(\mathrm{n}=6)$ acute. Computed tomography (CT) revealed delta sign in only two patients.

Patients were divided into two groups according to gender. Of all patients, $76.5 \%(n=26)$ were women. Clinical symptoms and demographic features were similar in women and men. Characteristics of the patients are shown in Table 1 (Table 1). Seizures

Table 2: Risk factors for cerebral venous sinus thrombosis

\begin{tabular}{lcc} 
& $\begin{array}{c}\text { Women (n=26) } \\
\mathbf{n ~ ( \% )}\end{array}$ & $\begin{array}{c}\text { Men (n=8) } \\
\mathbf{n ~ ( \% )}\end{array}$ \\
\hline Presence of risk factor & $22(84.62 \%)$ & $5(62.5 \%)$ \\
OCPs & $7(26.92 \%)$ & - \\
Pregnancy or purperium & $5(15.38 \%)$ & - \\
Hiperhomocysteinemia & $2(7.69 \%)$ & $1(12.5 \%)$ \\
Mastoiditis & $1(3.85 \%)$ & $1(12.5 \%)$ \\
Malignancy & $3(11.53 \%)$ & 0 \\
Behcet disease & $2(7.69 \%)$ & $1(12.5 \%)$ \\
Coagulopathies & $2(7.69 \%)$ & $1(12.5 \%)$ \\
Vasculitis & $1(3.85 \%)$ & 0 \\
Ulcerative colitis & 0 & $1(12.5 \%)$ \\
No risk factor identified & $4(15.38 \%)$ & $3(37.5 \%)$ \\
More than one risk factor identified & $2(7.69 \%)$ & 0 \\
\hline
\end{tabular}

OCPs: Oral Contraception Use during hospitalization did not differ between groups, but they tended to be more frequent in men. In patients who had seizures during hospitalization $(n=6)$, all had transverse sinus thrombosis; in two of them it was affected alone, in four of them it was occluded together with sigmoid sinus. Risk factors for CVST are shown in Table 2 (Table 2 ). We could not find any risk factors in $20.6 \%(n=7)$ of the patients. Overall, 3 patients had Behcet disease, 3 had malignancies, 3 had hyperhomocysteinemia, 2 had mastoiditis, 1 had protein $\mathrm{C}$ deficiency, 1 had antithrombin III deficiency and 1 had factor $V$ Leiden mutation. In 7 patients, the etiology remained unknown. The most common etiologic factor for women was the use of OCPs $(n=7)$. OCPs' users comprised the largest group $(n=7)$ in women. We could not find the etiology in four of the men. The distribution of occluded veins was similar. Transverse sinus was the mostly affected sinus as either alone or with the other CVST in both groups (in 20 women and 8 men). The distribution of venous sinus occlusion is summarized in Table 3 and Table 4 (Table 3 - 4).

Table 3: Distribution of occluded venous sinuses

\begin{tabular}{|c|c|c|c|c|}
\hline & $\begin{array}{c}\text { Women }(n=26) \\
n(\%)\end{array}$ & $\begin{array}{c}\operatorname{Men}(n=8) \\
n(\%)\end{array}$ & $\begin{array}{c}\text { Statistical analyses } \\
\qquad \chi^{2}\end{array}$ & $\mathbf{p}$ \\
\hline Straight sinus & $2(7.67 \%)$ & $1(12.5 \%)$ & 0.67 & NS \\
\hline Transverse sinus & $20(76.92 \%)$ & $8(100 \%)$ & 0.29 & NS \\
\hline Sigmoid sinus & $12(46.15 \%)$ & $5(62.5 \%)$ & 0.37 & NS \\
\hline Superior sagittal sinus & $12(46.15 \%)$ & $2(25 \%)$ & 0.42 & NS \\
\hline Jugular vein & $1(3.85 \%)$ & $1(12.5 \%)$ & 0.36 & NS \\
\hline
\end{tabular}

$\chi^{2}$ : Chi-square test, NS: Not Significant

Table 4: Distribution of the isolated and multiple CVST

\begin{tabular}{|c|c|c|}
\hline Localization of thrombosis & $\begin{array}{c}\text { Women }(n=26) \\
n(\%)\end{array}$ & $\begin{array}{c}\text { Men }(n=8) \\
\text { n ( } \%)\end{array}$ \\
\hline Superior sagittal sinus & $6(23.07 \%)$ & 0 \\
\hline Transverse sinus & $6(23.07 \%)$ & $3(37.5 \%)$ \\
\hline Transverse+sigmoid sinus & $6(23.07 \%)$ & $2(25 \%)$ \\
\hline Transverse+superior sagittal sinus & $2(7.69 \%)$ & 0 \\
\hline Transverse+sigmoid+ superior sagittal sinus & $3(11.53 \%)$ & $1(12.5 \%)$ \\
\hline Transverse+sigmoid+straight sinus & $2(7.69 \%)$ & $1(12.5 \%)$ \\
\hline Transverse+sigmoid+ superior sagittal sinus +jugular vein & $1(3.85 \%)$ & 0 \\
\hline Transverse+sigmoid+superior sagittal sinus+jugular vein+confluent sinium & 0 & $1(12.5 \%)$ \\
\hline
\end{tabular}

CVST: Cerebral Venous Sinus Thrombosis 


\section{DISCUSSION}

Cerebral venous and sinus thrombosis is a disease affecting all ages, but especially young women. The women tendency is supposed to be related with GSRF. In the International Study on Cerebral Vein and Dural Sinus Thrombosis (ISCVT) cohort study, $75 \%$ of the patients were women and women were older than men (5). In this study, similar to the literature, $76.5 \%$ of the patients consisted women. But mean age was similar in both groups. In our study, women/men ratio was 3.25/1 and the overall mean age was $33.26 \pm 11.93$.

Clinical presentation of CVST has a wide spectrum and may be nonspecific. There is not a defined syndrome (8). Whereas in some previous studies, it is reported that FND were more frequent as clinical presentation (9-11), in others $70-90 \%$ of the patients had headache at presentation $(5,7)$. In our study, headache was present in all patients and it was isolated in $47.1 \%(n=16)$ of them. ICH was the second most frequent presentation finding with a ratio of $38.2 \%(n=13)$. Eight $(23.5 \%)$ of the patients presented with FND. There was no significant difference between women and men for presentation symptoms. But the most common presentation symptom (43.78\%) in women was headache. And the most frequent presentation finding was ICH (34.78\%) in men.

In our study, onset of the symptoms was sub-acute in $52.9 \%(n=18)$ of the patients, chronic in $29.4 \%$ $(n=10)$ and acute in $17.6(n=6)$. The results of Crassard and Bousser's (12) study were very similar to our results. It was mentioned that acute onset was associated with focal signs and chronic onset was frequently observed in isolated ICH (13). In our study, similar results were found. Five of the 6 six patients with acute onset had FND and 7 of the 9 patients with chronic onset had ICH. In both women and men groups, sub-acute onset was more frequent (50\% and $62.5 \%$ ).

Many risk factors can be causative for CVST. It is important to define the etiological risk factors to prevent future thromboembolisms. Pregnancy and puerperium are the leading causes in young women. In Coutinho et al's (14) study, in women, OCPs usage was found in $46 \%$ of the patients. A recent meta-analysis showed that women using OCPs had an increased risk for CVST (5). Pregnancy, puerperium and OCPs usage are all GSRF for women and hormonal changes, hypercoagulability state, prothrombotic effect seem to be responsible $(15,16)$. Also, rearrangement of maternal cardiovascular circulation is another risk for postpartum period. Half of our women patients had GSRF; 7 (26.92\%) women were OCPs users and 5 (15.38\%) women were in pregnancy or puerperium period.

Different kinds of malignancies have been reported with CVST $(17,18)$. It was supposed that coagulation disorders, direct effect of tumor, therapeutic agents might be the reason (17). In our study, all patients with malignancy were women. In three $(11.53 \%)$ women with malignancy, one had breast cancer, one had acute lymphoblastic leukemia, and one had colorectal cancer. Rheumatological diseases are known risk factors for CVST. We established Behcet disease in three patients $(8.82 \%)$ as etiological factor for CVST. It is a low rate compared to the findings of previous studies in our geographical region. This may be related to either the increasing knowledge of other risk factors for CVST or early diagnosis and treatment of Behcet disease. Of the patients with Behcet disease, 2 (7.69\%) were women and $1(12.15 \%)$ was men. Although it did not reach statistical significance, Behcet disease was more frequent in the men's group. This may be related to the high prevalence of the disease in men. The specific clinical pattern of neurobehcet is involvement of the deep cerebral vein thrombosis (19). In our study, we identified sigmoid + transverse sinus thrombosis in all three patients with Behcet disease. In inflammatory bowel disease, thromboembolism is a well known complication; it can rarely be the causation of CVST (20). In our study, one patient in men group had ulcerative colitis.

In this study, CT was insufficient to reveal the diagnosis; in only two patients, delta sign was present. But, MRI and MRV had diagnostic value. There was no significant difference between women and men for affected sinuses. Some studies reported the superior sagittal sinus as the most frequently occluded one (21), we found that transverse sinus alone or together with sigmoid sinus was mostly frequently affected in both 
women and men group. Distribution of the affected sinuses either isolated or multiple were similar in both groups.

\section{REFERENCES}

1. Bousser MG, Ferro JM. Cerebral venous thrombosis: an update. Lancet Neurol 2007; 6:162-170.

2. Allroggen $\mathrm{H}$, Abbott RJ. Cerebral venous sinus thrombosis. Postgrad Med J 2000; 76: 12-15.

3. Tiede DJ, Tefferi A, Kochhar R, Thompson GB, Hay ID. Paraneoplastic cholestasis and hypercoagulability associated with medullary thyroid carcinoma. Resolution with tumor debulking. Cancer 1994; 73:702-705.

4. Saadatnia M, Tajmirriahi M. Hormonal contraceptives as a risk factor for cerebral venous and sinus thrombosis. Acta Neurol Scand 2007; 115:295-300.

5. Ferro JM, Canhao P, Stam J, Bousser MG, Barinagarrementeria F. Prognosis of cerebral vein and dural sinus thrombosis: results of the International Study on Cerebral Vein and Dural Sinus Thrombosis (ISCVT). Stroke 2004; 35:664-670.

6. Saadatnia M, Fatehi F, Basiri K, Mousavi SA, Mehr GK. Cerebral venous sinus thrombosis risk factors. Int J Stroke 2009 Apr; 4:111-123.

7. de Bruijn SF, Stam J, Kapelle LJ. Thunderclap headache as first symptom of cerebral venous sinus thrombosis. CVST Study Group. Lancet 1996; 348:1623-1625.

8. Cohen JE, Boitsova S, Itshayek E. Cerebral venous sinus thrombosis. IMAJ 2009; 11: 685-688.

9. Bousser MG. Cerebral venous thrombosis: diagnosis and management. J Neurol 2000; 247:252-258.

10. Breteau G, Mounier-Vehier F, Godefroy O, Gauvrit JY, Mackowiak-Cordoliani MA, Girot M, Bertheloot D, Hénon $H$, Lucas C, Leclerc X, Fourrier F, Pruvo JP, Leys D. Cerebral venous thrombosis; 3-year clinical outcome in 55 consecutive patients. J Neurol 2003; 250:29-35.

11. Baumgartner RW, Studer A, Arnold M, Georgiadis D. Recanalisation of cerebral venous thrombosis. J Neurol Neurosurg Psychiatry 2003; 74:459-461.
As a conclusion, we have found differences between women and men in the presentation and risk factors.

12. Crassard I, Bousser MG. Cerebral venous thrombosis. J Neuroophthalmol 2004; 24:156-163.

13. Biousse V, Bousser MG. Cerebral venous thrombosis. Neurologist 1999; 5:236-249.

14. Coutinho JM, Ferro JM, Canhão P, Barinagarrementeria F, Cantú C, Bousser MG, Stam J. Cerebral venous and sinus thrombosis in women. Stroke 2009; 40:2356-2361.

15. Cantu C, Barinagarrementeria F. Cerebral venous thrombosis associated with pregnancy and puerperium. Review of 67 cases. Stroke 1993; 24:1880-1884.

16. Vandenbroucke JP, Rosing J, Bloemenkamp KW, Middeldorp S, Helmerhorst FM, Bouma BN, Rosendaal FR. Oral contraceptives and the risk of venous thrombosis. N Engl J Med 2001; 344:15271535 .

17. Raizer JJ, DeAngelis LM. Cerebral sinus thrombosis diagnosed by MRI and MR venography in cancer patients. Neurology 2000; 54:1222-1226.

18. Lopez-Pelaez MF, Millan JM, de Vergas J. Fatal cerebral venous sinus thrombosis as major complication of metastatic cervical mass: computed tomography and magnetic resonance findings. J Laryngol Otol 2000; 114:798-801.

19. Mossadeq R, Karouache A, Bouraza A, Ouhabi H, Reda R, Boutaleb $\mathrm{N}$ et al. Neuro-Behcet's syndrome and thrombosis of Rosenthal's basilar vein: a report of twelve cases. Rev Neurol (Paris) 2004; 160:935-938.

20. Srivastava AK, Khanna N, SardanaV, Gaekwad S, Prasad K, Behari M. Cerebral venous thrombosis in ulcerative colitis. Neurol India 2002; 50:215-217.

21. Terazzi E, Mittino D, Rudà R, Cerrato P, Monaco F, Sciolla R, Grasso E, Leone MA, Cerebral Venous Thrombosis Group. Cerebral venous thrombosis: a retrospective multicentre study of 48 patients. Neurol Sci 2005; 25:311-315. 